\title{
KULTURENS MYSTERIUM TREMENDUM
}

\section{Lydia Wahlström}

Lydia Wahlström (1869-1954) var en av den svenska kvinnorörelsens färgstarkaste företrädare, engagerad i tidens stora frågor och ständigt på språng från det ena uppdraget till det andra. Politiskt sett stod hon till höger, vilket det inte var många som gjorde av rörelsens frontfigurer. Hon kom till Uppsala 1888 och var med om att bilda en kvinnlig studentförening, något som nog kunde behövas. De kvinnliga studenterna var få och den patriarkala kulturen inom akademien hade månghundraåriga anor.

1898 disputerade hon i historia och blev därefter studierektor på Åhlinska skolan, eftersom universitetskarriären var stängd för kvinnor. Egentligen ville hon bli präst som sin far, men det yrket var ända fram till 1958 förbehållet män. ${ }^{1}$ Som så många av sin tids intellektuella kvinnor var Lydia Wahlström djupt involverad i rösträttsrörelsen. Hon var med om att bilda Landsföreningen för kvinnans politiska rösträtt, LKPR, och var under många år en av dess flitigaste skribenter och talare. Samtidigt skrev hon mängder av artiklar och böcker i skilda ämnen. Hennes produktivitet var överväldigande.

Som om detta inte var nog skrev hon tre självbiografiska romaner, Daniel Malmbrink (1918), Sin fars dotter (1920) och Biskopen (1924). Wahlström tycks ha haft en viss fäbless för självbekännelser. "Jag känner det faktiskt ibland, som om jag jagade mig själv som en mal genom ett rum under soffor och bakom byråar för att slutligen få mig fast", låter hon ett av sina fiktiva alter egon säga. ${ }^{2}$ I "Personliga erfarenheter av psykoanalys" berättade Wahlström vid 76 års ålder modigt om sin sexualitet och hon avslutade sitt självreflexiva skri- 
vande när hon vid 80 års ålder publicerade memoarboken Trotsig och försagd (1949).

Wahlström tycks ständigt ha varit förälskad - lyckligt eller olyckligt - i kvinnor som med åren blev allt yngre än hon själv. ${ }^{3}$ I det levda livet kunde den förbjudna kärleken gömmas bakom vänskapens mask. I memoarerna likaså. I romanerna om Daniel Malmbrink förläggs kvinnokärleken till en heterosexuell man medan den i Sin fars dotter figurerar som romantisk vänskap. På så sätt kringgicks (det inofficiella) yttrandeförbudet.

Wahlströms vän och yrkeskollega, historikern Alma Söderhjelm, tillika Finlands första kvinnliga professor, valde ett tredje sätt att lösa samma problem. I de två romanerna Kärlekens väninna (1922) och Den flygande holländaren (1923), som publicerades ungefär samtidigt som Wahlströms, förlade hon de förbjudna begären till en grupp homosexuella män. Detta grepp desarmerade det farliga ämnet - Söderhjelm var ju inte man och kunde därför knappast misstänkas för att vara en homosexuell man. Alltså var berättelserna inte självbiografiska. Men skandal blev det ändå. ${ }^{4}$

Kamouflaget var inte heltäckande i vare sig Wahlströms eller Söderhjelms berättelser. Båda låter det förbjudna skymta fram här och var för den som har ögon för sådant, samtidigt som övriga läsare inte oroas. Fenomenet brukar kallas queert läckage. Ändå var Wahlström inte säker på att läsarna verkligen såg det, för i självbiografin ger hon nycklar till den levda värld som romanerna skildrar. Lägger man de självbiografiska berättelserna vid sidan av de skönlitterära uppstår nya betydelserum, med plats för känslor, tankar och handlingar som det annars var omöjligt att skriva om annat än på ett avståndstagande sätt. ${ }^{5}$

\section{Lydia och Daniel I}

Genom att skjuta en manlig karaktär framför sig kunde Wahlström berätta om egna (förbjudna) kärlekserfarenheter. Konstruktionen gjorde det möjligt att skriva om utsvävningar på kärlekens område, om andligt sökande, om olycklig förälskelse och djup kris i livet. Med Daniel Malmbrink som sköld kunde hon berätta om den 
lockelse en kvinna kan utgöra, men priset var att allt som hade att göra med kriminalisering och marginalisering, den samkönade kärlekens samhälleliga existensvillkor vid den här tiden, samtidigt osynliggjordes.

Daniel Malmbrink är ingen dokumentärroman, men likheterna mellan dess huvudperson och dess författare är iögonenfallande: båda skriver böcker om protestantism och katolicism och båda jämför förhållandena i Sverige och England. ${ }^{6}$ Daniel är präst, ett yrke som Lydia själv skulle velat ha: "Naturligtvis hade jag tidigt klart för mig, att jag skulle bli präst, eftersom jag i allt ville likna min far, och min första väckelse till kvinnosak kom nog, när jag upptäckte, att jag som kvinna inte kunde få hans ämbete." Daniel är "skygg och framfusig" och sig själv beskriver författaren som "trotsig och försagd". I memoarerna underströk Wahlström närheten mellan sig själv och sin manlige hjälte: "För Malmbrinktypen hade jag för övrigt min modell på närmaste håll - mig själv, sådan jag föreställde mig att jag skulle blivit, om jag varit man och därtill en fruntimmersbortskämd präst."

$\mathrm{Nu}$ var hon ju varken man eller präst, men fruntimmersbortskämd tycks Wahlström ha varit. 1902 citerade hon ett brev från ett av sina ex: "Och så sa' hon, att hela denna generation måste ympas med något serum mot mig, som man ympar mot difteri och smittkoppor", något som väl säger en del om hennes förföriska kraft. ${ }^{10} \mathrm{I}$ memoarerna citerar hon en vers som kamraterna sammanknåpat till hennes ära: "Lydia, säg, vid alla gudar jag dig därom besvär: varföre så du skyndar att oss fördärva genom kärlek." ${ }^{11}$

I memoarerna hymlar Wahlström inte om sina många svärmerier, även om hon av lätt insedda skäl inte skriver fram dem så tydligt som hon förmodligen skulle ha gjort om hon hade levt i en annan tid. När hon lämnade in sin första roman till Norstedts var hon "ännu inte fullt säker på vad det var för något jag skrivit - roman eller självbiografi!"12 Belåtet och lite förvånat konstaterar hon att kritikerna inte verkar ha lagt märke till det självbiografiska momentet i texten utan accepterat berättelsen som ren fiktion:

Egentligen var det hela komiskt: jag slungar ut min självbekän- 
nelse och vet inte alls om det är skönlitteratur eller ej, och så får jag av en kännare höra, att jag gjort "ett ypperligt psykologiskt konstverk med en förbluffande färdighet i handhavande av min konsts medel".13

Det fanns till och med kritiker, berättar hon, som tyckte att hon varit lite väl sträng mot Daniel och särskilt de manliga läsarna tog honom i försvar.

Verkligt komiskt var det att höra en annan mera välvilligt stämd Uppsalakamrat, författaren Erik Brogren, fundera över om min modell nu var lyckligt omgift. När jag inte kunde upplysa om saken, satte han till sist i fråga, om jag inte vore skyldig ta hand om honom - alltså gifta mig med mig själv! ${ }^{14}$

Ändå var det nog många människor i Wahlströms närhet som kunde se igenom kamouflaget. Karin Boye, Wahlströms elev och även bekant med henne, gjorde det i alla fall. Hon ansåg romanen "psykologiskt betydande men konstnärligt obetydlig" och "beundrade modet hos den som så hade vågat avslöja sig själv"."15

Både Daniel och Lydia står mitt i livet, har flicktycke och har i sin ungdom gett efter för de många frestelser som detta har medfört. De är intelligenta, receptiva och handlingskraftiga, men de är också självkritiska och enligt egen utsago lite socialt klumpiga. Det finns mängder av egenskaper som Wahlström tillskriver Daniel i romanen som hon senare tillskriver sig själv i memoarerna, men det finns också skillnader mellan dem, troligen tillagda för att hålla Danielgestalten på lite avstånd. Den mest iögonenfallande detaljen är att Daniel är hopplöst reaktionär i kvinnofrågor och bland annat tycker att "studentmössan alltid är missklädsam på flickor" - Wahlström och hennes kamrater i kvinnliga studentföreningen hade varit först i landet med att bära studentmössa i offentliga sammanhang, något hon stolt framhåller i memoarerna. ${ }^{16}$

Daniel säger pompöst att han föredrar "kvinnliga kvinnor" och kanske tyckte Wahlström något liknande om kvinnor som hon erotiskt attraherades av, men i sin egen själviscensättning underströk 
hon som regel det manliga. Talet om manhaftiga studentskor hade författaren hört till leda. Själv utgjorde hon inbegreppet av den kvinnlighet som Daniel är så kritisk till, och hon hade själv blivit utsatt för trakasserier på grund av detta. Uppsalas kvinnliga studenter blev exempelvis föremål för ett nidporträtt i en tysk tidskrift: "vi 'svärmade omkring på gatorna' (femton stycken) och fördunklade das ewig Weibliche 'mit Pincenez, kurzgeschorenen Haaren (som ingen enda av oss hade) und einem krummen Rücken"'.17

I memoarerna påstår hon alltså att ingen av dem skulle ha haft kortklippt hår, något som dock inte var sant. I Trotsig och försagd finns en bild av Wahlström som student där hon är klädd i en uniformsliknande klänning, studentmössa och kortklippt hår. Där finns också en målning gjord några år senare, där hon poserar i en elegant kappa, har studentmössa på huvudet och en pincené på näsan. Det där med krum rygg var däremot en antifeministisk kliché. Wahlström var en hängiven frisksportare och bilderna visar en kraftfull kvinna med rakryggad hållning. "Denna emancipissa, cyklist och friluftsmänniska från vandrarepokens tid, betraktad som 'maninna' av emancipationens fiender och som skräcködla av ganska många män, var en av de självständigaste människor jag råkat", skrev Erik Hjalmar Linder i sina minnen. ${ }^{18}$ Intresset för att cykla, vandra i naturen och frisksporta var något hon delade med många andra kvinnosakskvinnor. Det ingick som en del i kvinnorörelsens befrielseföretag.

Den största skillnaden mellan romanens Daniel och memoarernas "jag" är att han är en heterosexuell man medan hon är en kvinnoälskande kvinna. Hans kärlek tas på allvar av alla (utom den älskade) och giftaslystna kvinnor flockas runt honom. Det fanns gott om kärlek även för Lydia, men hennes kärlekserfarenheter och hennes kärlekslängtan hade ingen plats i det homofoba samhälle hon levde i. Sådant fick stanna i kretsen av förtrogna.

Romanerna uppfattades inte som kontroversiella när de kom, men om läsarna hade känt till de nycklar till det förbjudna som Wahlström sedan skulle ge i memoarerna skulle det kanske ha blåst upp till storm. Det ligger tre decennier mellan romanerna och memoarerna och mycket hade hunnit hända. Homosexuella handling- 
ar var nu inte längre straffbara, men den grundmurade homofobin skulle dröja sig kvar många, många år framåt. Det var modigt av Wahlström att skriva att Daniel Malmbrink hade med hennes eget liv att göra:

Den första av mina romaner är direkt, om också länge omedvetet, inspirerad av en elev, som efter sin förtidiga död från fem barn 1936 alltjämt står för mig som det ljusaste minnet från hela min långa skolverksamhet. I hennes gestalt koncentrerade sig för mig all den poesi jag mött i ungdomsrörelsen. Det var också på ett gymnasistmöte som hon, 19-åringen, blev medveten om det inflytande hon redan under ett år omedvetet haft över mig. ${ }^{19}$

Och om romanens känslosammanhang skriver hon:

Min beröring med Ellen Amman och min brytning med en elev 1917 sammansmälte slutligen till fantasier om en svensk präst, som under katolskt inflytande i England blir frestad att lämna sin egen kyrka. $^{20}$

Wahlström tillbringade en månad på Sigtunastiftelsen tillsammans med en tidigare elev när hon arbetade som mest intensivt med romanen: "Snart började Daniel utvecklas självständigt, oberoende av sin författare, och Lisa levde med och sökte ibland tala gott för stackars Daniel, som hon tyckte jag började bli väl stygg emot." ${ }^{21}$ Romanskrivandet fortsatte sedan hos paret Sigrid Leijonhufvud och Sigrid Blomberg och därefter hos Anna Danell, en kvinna som Wahlström tidigare hade velat leva tillsammans med och som hon på sätt och vis faktiskt också kom att dela sitt liv med, trots att Anna gifte sig och Lydia träffade andra kvinnor. ${ }^{22}$

Denna gång gjorde hon mig en ovärderlig väntjänst, då hon nämligen skaffade mig tillfälle att för en $\mathrm{f}$. $\mathrm{d}$. elev läsa upp de partier av mitt Danielmanuskript, där teckningen av hjältinnan innehöll utdrag av brev. Jag var då på fullt allvar beredd att på grund av den unga flickans rädsla för ogrannlaga avslöjanden avstå från hela 
tryckningen. Efter min uppläsning fann hon emellertid Eleanors förklädnad så fullständig, att tanken på boken inte mer kunde skrämma henne. ${ }^{23}$

\section{Daniel och Oscar}

Den samkönade kärleken är maskerad till heterosexualitet i Daniel Malmbrink, men det förbjudnas känslovärldar är på många sätt ändå närvarande i romanen - för den som vill se vill säga, för det går utmärkt att läsa boken även utan att lägga märka till dem. Mest iögonenfallande är att de viktigaste intertexterna till romanen är Oscar Wildes The Picture of Dorian Gray (1891) och De Profundis (1905), texter som var mycket starkt förknippade med homosexualitet vid den här tiden och som väl knappast är vad man tänker sig att en svensk landsortspräst skulle ha liggande på nattduksbordet. Romanen förbigår visserligen det samkönade momentet i Wildes texter och lyfter i stället fram det existentiella, men det förbjudna finns ändå närvarande. Oscar Wilde var vid denna tid utan jämförelse det litterära Europas mest omtalade homosexuelle författare, ryktbar för sin vassa tunga och för att ha blivit dömd till två års fängelse för homosexuella handlingar efter en rättegång som dag för dag hade följts av en sensationslysten skvallerpress. Det var i denna rättegång som uttrycket the love that dare not speak its name blev ett allmänt bekant uttryck för samkönad kärlek.

Romanen Daniel Malmbrink bygger förbindelser mellan Daniel och Dorian Gray och mellan Daniel och den Oscar Wilde som är textens jag i De Profundis. Gång på gång liknar Daniel sig själv vid Dorian Gray, den vackre ynglingen som har njutning och skönhet som enda ledstjärnor vilket så småningom gröper ur honom själsligen. Också Daniel har varit bortskämd med kärlek och glupskt tagit för sig. Han läser sig sömnlös på "Dorian Gray, den vidriga spökboken", och tycker att han "liksom känt igen sig där". ${ }^{24}$ Han "hade något av Dorian Gray - denna evigt oföränderliga ungdom under stigande ruttenhet, masken i hjärtat, men ansiktet och gestalten alltjämt lika ungdomliga!” (93) Också Daniel upplever att han själsligen håller på att urholkas. Men när han sedan går in i kris och 
depression omvärderar han sitt förflutna. "Han hade en gång sett sig själv som Dorian Gray, men det hade bara varit självöverskattning det också. Daniel Malmbrink dugde visst inte till någon demonisk ondska; han var enbart löjlig." (333) Spänningen mellan å ena sidan självbelåtenhet och å andra sidan psykisk nedbrytning finns till och med inskriven i Daniels namn: "malm" är ett metalliskt material som i romanen förknippas med styrka och sundhet medan "brink" är en urgröpning vid en strandkant åstadkommen genom erosion.

Förbindelserna mellan Daniel Malmbrink och De Profundis är om möjligt än starkare. Daniel och Oscar Wilde är lika gamla, 42 år, när de står inför sina livskriser, båda älskar en betydligt yngre person och det är den äldre parten som blir sviken och som slutligen förlorar fotfästet i tillvaron. Wahlströms roman handlar precis som Oscar Wildes om ett sammanbrott. Daniel läser De Profundis och känner igen sig i den känslovärld som skildras där:

"Livet måste tas emot i tyst andakt." Hade han inte varit frestad att skriva anammas, men funnit det alltför likt något citat han en gång hört? Nu visste han vad det var; det var orden i Oscar Wildes "De Profundis":

"Kärleken är ett sakrament och måste anammas på knä." (220)

Det finns en skabrös tolkning av Wildecitatet, som ligger nära till hands om man ser det taget ur sitt sammanhang, men som är avlägsen i De Profundis som helhet. Den är förstås inte heller aktuell för vare sig Daniel eller den roman där han är hjälten. Här handlar det om vördnad inför kärleken, både den världsliga och den gudomliga. Både i De Profundis och Daniel Malmbrink är längtan efter den älskade intimt sammantvinnad med längtan till det gudomliga i Jesus gestalt. Daniel dras till katolicismen för att den för honom framstår som mer sinnlig än protestantismen. Oscar Wildes De Profundis har fătt sitt namn från Psaltarens psalm 130 som börjar: "Ur djupen ropar jag till dig, Herre. Herre, hör min röst, låt dina öron akta på mina böners ljud." Det är en bön om förlåtelse och förlossning, en bön som jaget i Oscar Wildes text söker sig till i förtvivlan och som ekar även i Wahlströms roman. 
Men det är inte nog med att den beryktade Oscar Wilde ges så stor plats i romanen. Även andra författare som kan förknippas med samkönad kärlek dyker upp i texten. Det berättas till exempel att Daniel i sin ungdom hade känt sig hemma i "den Wikner-Rydbergska tankevärlden med det Wallinska: 'Var är den vän, som överallt jag söker', till symbol”. (259) Detta var en form av svärmisk religiositet där den innerliga (samkönade) vänskapen och kärleken till Gud vävdes samman. Denna tankevärld hade tilltalat Wahlström själv och nu låter hon sitt alter ego intressera sig för den, men i hans fall har den samkönade kärleken omvandlats till heterosexualitet. '"Eleanor, tänkte han, 'är det en hädelse, att jag alltid talar till dig i samma ord som till Gud? Eller är du inte Guds gissel för mig? Ack, om du också ville vara Guds nåd."'(92)

Att texter av författare som Viktor Rydberg och Pontus Wikner kunde läsas in i en homoerotisk litterär tradition var förmodligen ingenting som den genomsnittliga läsaren kände till, men för den som aktivt sökte efter litterära gestaltningar av samkönad kärlek låg det närmare till hands. Klart är att såväl Rydberg som Wikner hade stor betydelse för Wahlström som ung. Klart är också att hon hade blick för det samkönade momentet i flera av Wikners texter. ${ }^{25}$ I den redan nämnda artikeln "Personliga erfarenheter av psykoanalys" band hon ihop sitt eget livs svärmerier med Pontus Wikners personliga liv och texter:

Och var man då, som alla människor den tiden, fullständigt okunnig i sexualpsykologi, var det lätt att glida in i en vänskapserotik, som kunde börja i anden och lykta i köttet, men som i så fall alltid slutade med vämjelse och brytning och nytt letande efter idealet. Mycket av detta - både de högspända fordringarna på vänskapsförhållandets renhet och den fullständiga okunnigheten om vart gränsfallen kunde leda, när det vill sig illa - hittar man i Pontus Wikners liv med dess segrande kamp och dess långa lidande. Fast hans anteckningar ännu inte äro tillgängliga, framgår dock tillräckligt därav både ur hans brev och hans båda förnämliga betraktelser, Kulturens offerväsen och Narkissossagan och platonismen. ${ }^{26}$ 
Att det inte är någon tillfällighet att just dessa namn nämns i romanen blir tydligt också genom att även andra författare som på ett eller annat sätt har beröring med samkönad kärlek dyker upp. Här finns Alphonse Daudet och Joris-Karl Huysmans, upphovsmän till beryktade romaner som Sapho (1884) respektive À rebours (1884). Och här finns Vernon Lee, pseudonym för författaren Violet Paget, som alltid klädde sig à la garçonne, som levde tillsammans med kvinnor och som var en del av samma litterära rörelse som Oscar Wilde.

Vernon Lees namn dyker upp i romanen när frågan om kvinnors beroende eller oberoende av män avhandlas. När Daniel har uttryckt sig dumdrygt patriarkaliskt får han svar på tal: "Har Ni inte hört talas om den gamla damen, som hade en papegoja som svor och en pudel som åt tobak, och som tyckte hon hade det precis som om hon varit gift." ${ }^{27}$

\section{Romanen}

Daniel Malmbrink handlar om kontraktsprosten Daniel, som har en minderårig son och en faster som förestår hans hushåll. Ändå upplever han tomhet i livet. Han har inte sin sak klar med Gud, tänker en gammal kollega i romanens inledningsscen. Det visar sig att han inte har sin sak klar med kärleken heller och balansen i båda dessa känslovärldar rubbas än mer av att de ständigt blandas samman. Daniel har förlorat sin hustru och åker utomlands för att, som han säger, resa ifrån sorgen, men den gamle själasörjaren tänker att "han har ingen sorg att resa ifrån". Detta "stora bortskämda barn, som aldrig haft ekonomiska bekymmer, aldrig varit sjuk, alltid 'haft tur' både i kärlek och befordringsväg". (16)

I ett samtal mellan två av Daniels gamla bekanta fortsätter karaktäristiken av honom. Den ene av dem är läkare och det är han som på tidstypiskt manér får utsäga de kritiska sanningarna om Daniel: "Från Uppsala-tiden och sin första tjänstgöringstid blev han ju känd nästan som typisk erotoman." (26) En remarkabel sak att säga om en figur som författaren senare annonserade ut som ett självporträtt. Daniel har haft den ena kärlekshistorien efter den andra, alltid lika 
säker på att den här gången var det på allvar. ”Det var ju det som gjorde, att man inte bara blev ond på honom, att han så löjligt bedrog sig själv med alla sina omvändelser, endera till nya flickor eller nya religioner - vilketdera kommer precis på ett ut, eller hur? Det ena var ju ändå bara surrogat för det andra.” (26) Daniel är en stilig man. Så tycker kvinnorna och så tycker han själv. Samtalet mellan de båda vännerna fortsätter:

\begin{abstract}
"Egentligen tycker jag inte det är så farliga saker du har berättat om honom; det är ju inte värre än en hederlig karl mycket väl kan tåla vid. Åtskilligt av det är kanske, när allt kommer omkring, bara bevis på att han är en riktig karl, och det finner väl en läkare normalt, när man skall anse erotiken för det enda verkliga, eller hur", tillade han spydigt. - "Han bär sina fel på bricka, så dem sörjer han för, att man genast får se; men se’n vet man också det värsta och har bestämt inga fler ledsamma upptäckter att göra." (35)
\end{abstract}

Sådan är hjälten när berättelsen tar sin början, "en typisk erotoman", "en hederlig karl", "en riktig karl", men också en man med ett flyktigt känsloliv, rastlöst sökande både andligt och erotiskt. Han tycker sig vara i färd med att bli en karikatyr av sig själv och reser till England för att få en nystart i livet. Han tar kontakt med en katolsk präst och i samtalen med honom närmar han sig katolicismen. Samtidigt umgås Daniel med prästens syster, den betydligt yngre Eleanor. Till en början låter hon sig uppvaktas av honom, men i takt med att hans förälskelse blir starkare blir hennes svagare och när Eleanor sedan lämnar honom bryter han ihop. Han har förvandlats från en njutningslysten Dorian Gray till den förkrossade Oscar i De Profundis.

Berättelsen vittnar om förtrogenhet med själslig kris, men problemet är att romanens huvudperson är alltför privilegierad på livets alla områden för att kunna förkroppsliga den förtvivlan som texten handlar om. Det blir inte övertygande när berättelsen om Daniel parallellställs med berättelsen om Oscar. Den senare förlorade ju inte bara sin älskade utan också sitt namn, sin karriär, sina vänner och sin familj. Det är när Oscar i fängelset, dömd till två års straffarbete, får reda på att hans son kommer att tas ifrån honom som han 
faller ihop på knä inför Gud. ${ }^{28}$ Wilde skrev De Profundis i fängelset, i spillrorna av det som en gång hade varit hans liv. Daniel förlorar just ingenting utom Eleanor. Han har helt enkelt bara fått nobben.

Romanen låtsas inte om den obönhörliga heteronormativitet som drabbade både Wilde och Wahlström själv, men som på alla sätt privilegierar Daniel. Den förtvivlan som är berättelsens känslomässiga nav kan helt enkelt inte härbärgeras av denne goddagspilt.

\section{Lydia och Daniel II}

Författaren tillskriver sin manlige hjälte mängder av personliga och yrkesrelaterade detaljer som är hämtade från hennes eget liv, men hon ger honom också tankar och repliker, särskilt i könspolitiska frågor, som var henne själv främmande. Hon låter honom läsa litteratur av såväl skön- som facklitterärt slag, som hon säkert hade läst själv men som det kanske inte är så troligt att en svensk landsortspräst skulle ha intresserat sig för.

Här och var finns det glipor i berättelsens förklädnad, där underliggande världar lyser igenom. Daniel säger till den katolske prästen: "Det låter kanske motbjudande för Er, men fast jag inte har någon direkt religiös längtan efter Kristus, skulle jag vilja vara så att säga 'normal' i religiösa ting." (52; min kurs.) Ordvalet är intressant. Dels för att begreppen "normal" och "onormal" var så centrala kategorier i tidens sexualitetsdiskurs, dels för att religion och erotik så konsekvent blandas samman i Daniels föreställningsvärld: "Ack, jag har alltid liksom rört ihop erotik och religion", säger han. (201)

Prästen utgår från att hans syster ska vara reserverad mot "en sådan man som Daniel". (125; min kurs.) Vad "sådan" i detta sammanhang syftar på framgår egentligen inte. Som tidigare nämnts betydde ordet vid denna tid ofta en person som begär människor av sitt eget kön. Alma Söderhjelm använde i en av sina romaner ordet om både män och kvinnor just i den betydelsen - "sådana herrar" och "sådana flickor". ${ }^{29}$ En annan gång säger Daniel: "Det är inte utan, att jag ibland nästan undrat över att $\mathrm{Ni}$, som är människokännare och kanske redan anat något om mig, inte dragit Er för att låta $\mathrm{Er}$ syster vara så mycket tillsammans med en sådan som mig." (139; min 
kurs.) "Anat något om mig"? "En sådan som mig"? Orden öppnar en glipa in mot det förbjudna. Daniel anspelar också på förmoderna förståelser av sexualiteten: "om någon behöver få det kroppsliga helgat för sig, så är det jag. Det står ju, att 'detta slags djävlar gå icke ut utan bön och fasta', men jag har alltid funnit, att de även trots bön och fasta komma igen på tusen sätt." (134-135)

Daniel längtar efter närhet - men kan inte ta emot den. Han är övertygad om att hans begär skulle upphöra om den älskade gav efter för honom. Det finns en djup konflikt inbyggd i den kärlek det talas om i romanen, en konflikt som dock är illa förankrad hos dess privilegierade heterosexuelle hjälte. Daniels kärlek till Eleanor är inte förbjuden och det demoniska momentet i följande passage kan därför läsas som ännu en glipa i förklädnaden:

Hur kom det sig, att längtan efter henne alltid blev dubbelt stark, när hon såg så där intensivt renhjärtad ut som hon nu gjorde? Var det inte så, att för hans klåfingrighet det rena alltid varit lika med det oåtkomliga? Han hade ju varit precis som småbarnen, som ska ha allt vad de tycka om i bädden hos sig eller stoppa det i munnen eller krama sönder det i ett famntag. Men det hade också alltid slutat med, att han sedan bara slungade leksaken för att gå över till nästa och göra på samma sätt med den. Ack, och han var ju ändå till sist intet barn, han var endast och allenast det gamla bergtrollet med trollets ofrånkomliga kannibalinstinkter! (123-124)

"Klåfingrighet"? "Det gamla bergtrollet"? "Kannibalinstinkter"? Sådana ord hörde hemma i det förbjudnas konnotationssfär vid denna tid. ${ }^{29 b}$ Tankegången liknar den som finns i den tidigare citerade passagen ur "Personliga erfarenheter av psykoanalys" och som handlar om Lydias eget pendlande mellan den idealiserade vänskapen och den tabuerade sexualiteten. Men den passar inte ihop med Daniels personlighet. Vari hans skurkaktighet egentligen skulle bestå framgår inte. Han försöker inte våldföra sig på henne. Han vill bara gifta sig med henne. Ändå finns det ett moment av våld i de intima scenerna: 
Han hade en besynnerlig känsla av att det endast var trollsömn hon sov, men han var inte riddaren, som hade makt att väcka henne och i vars armar hon skulle kasta sig; han var snarare trollet, som sövt henne och nu hade glömt väckningsformeln. Skulle hon inte när som helst varit färdig att störta upp med ett skrik och fly undan honom ifall hon fått se hans rätta skepnad? Hon måste ju en gång komma att straffa honom för stunder som dessa! (205)

"Trollsömn"? "Hans rätta skepnad"? "Trollet"? Återigen ord som förekom i tidens diskurser om samkönad kärlek men som inte motiveras av berättelsen. Och ett sista exempel. Daniel och Eleanor sitter i ett bibliotek och ser hur kvällsskuggan smyger sig allt längre upp längs bokryggarna tills den sista solstrimman kryper upp mot taklisten. Som om de sakta höll på att sjunka ner från en ljus dagvärld till en mörk och otämjd nattvärld. Daniel upplever sig som en drunknande. Han kysser henne:

Vid hans kyss öppnade hon långsamt ögonen, och den blick hon då gav honom glömde han aldrig. Det var först något av den hårda metallglansen igen, men den hade han ju sett många gånger förut. Det värsta var vad som efterträdde denna blick: en blixt av motvilja, äckel, vämjelse, som snörde ihop hans själ av fasa. Nej, detta var inte heller det värsta: innan fasan ens hunnit övergå till medveten tanke hos honom, slöt hon ögonen, tryckte sina läppar hårt mot hans och lade sig intill honom igen. Och nu kom det värsta: att han ändå inte kunde skydda detta unga liv mot sig självt, utan återgäldade hennes kyss med en mans hela våldsamhet, fast han hela tiden kände sig klarvaket och ohyggligt iakttagande, liksom räknande hennes pulsslag, såsom vivisektorn räknar det pinade djurets, i visshet om att det snart skall dö. (207)

"Motvilja"? "Äckel"? "Vämjelse"? "Fasa"? Varför dessa starka ord? Relationen mellan Eleanor och Daniel kan inte härbärgera den laddning som finns i dem. "Vivisektion"? Daniel tänker på kyssen i ord som har hämtats från de diskurser som framställde samkönad 
förförelse som ett övergrepp, där en erfaren part slog klorna i en oerfaren, en äldre i en yngre eller en "onormal" i en "normal".

Daniel är förälskad i Eleanor och hon är inledningsvis ganska road av honom, men däremot saknas de destruktiva krafter som skulle kunna framkalla den ångest som berättelsen kretsar kring. "Är inte Eros i grunden en hedning", säger Eleanor, en replik som framkallar den första kyssen, men redan i nästa ögonblick förändras det känslomässiga landskapet. Nu tycker både han och hon att han har skadat henne, utan att man som läsare förstår varför. Det finns ett glapp mellan de laddade orden och de ganska triviala händelser som romanen berättar om. Orden är helt enkelt hämtade från andra känslovärldar än de som romanens privilegierade hjälte rör sig i. ${ }^{30}$ Kanske från författarens eget liv. Klara Johanson, senare känd som signaturen K.J., hade under 189o-talet en kärleksrelation med Lydia Wahlström som slutade sorgligt för Klaras del. I ett brev till en gemensam bekant från 1898 ser Klara Johanson tillbaka på relationen med Wahlström:

Du måste försöka inse, att det var så mycket fint ock rent ock ideellt med, att det för mig åtminstone alldeles höljde in ock förskönade det andra. Utom att jag hade forngrekiska åsikter i vissa fall, långt innan jag hade läst Plato. För henne, som alltid haft anlag för religiös ruelse och alltid känner sig som samhällsmedlem, hade det mera olyckliga verkningar. Hon har aldrig brukat spara på anklagelserna mot sig själv. ${ }^{31}$

\section{Biskopen}

Några år senare kom en fortsättning på berättelsen om Daniel Malmbrink, nämligen Biskopen. Det har nu gått några år och det är dags för Daniel att förälska sig igen, denna gång är det den nitton år yngre Carry som blir föremål för hans låga. "Kjaerligheden hos sangviniske Naturer er altid bestandig - den skifter kun Gjenstand", säger dansken Erik Bögh och Daniel känner sig träffad. Lydia också, kan man tänka, för hon citerade orden även i sina memoarer. ${ }^{32}$

I sitt arbete med romanen utgick Wahlström från en dagbok 
hon förde från 1918 och några år framåt och som hon kallade för "Biskop Malmbrinks dagbok", och hon uppger i memoarerna att Carrygestalten är "fullständigt kalkerad på min elev Anita Nathorsts brev". ${ }^{33}$ Carry är - i likhet med Anita Nathorst - en Puckgestalt, androgyn, smart och livsbejakande. "Livet är bestämt bäst", säger Carry, "när det inte alls är inriktat och konstruerat, utan får fritt följa den inneboende lagen, Gud i människan. Och varför skulle den lagen inte också kunna yttra sig i till exempel dragningen till skönhet och viljan till glädje?" (89) Om än i inlindad form skulle detta kunna läsas som ett försvar för den samkönade kärleken.

Det skulle föra för långt att djupare gå in i även denna roman. Det får räcka med ett par detaljer som anknyter till självbekännelsetemat. Carry tänker på Daniels rykte:

$\mathrm{Nu}$ kunde hon heller inte längre avvisa de små avgrundsandar, som så ofta flugit för vinden omkring henne. Att han före sitt äktenskap varit "en smula vidlyftig", den viskningen följde ohjälpligt i hans spår. På sitt oförsiktiga maner hade han också gett spridning däråt genom att strax efter brytningen med Eleanor predika "synd och nåd" på ett sådant sätt, att de mindre vetande, som vanligen utgjorde flertalet i åhörarskaran, fingo intrycket, att han själv var den botfärdige rövaren eller den ur elden ryckta branden. (241)

"De mindre vetande" resonerar alltså ungefär som jag gör här, och även denna passage kan läsas som en gest riktad ut ur fiktionen och rakt in mot berättelsen om det levda livet.

Carry och Daniel åker till Italien, precis som Lydia och Anita en gång hade gjort. De är varmt förälskade och möts i ömsesidig sinnlighet, men Daniel förmår inte njuta fullt ut av den kärlek han får. Han har så länge levt med en avgrund mellan kropp och själ och trott att det lidande som detta medfört har varit förädlande. Han har svårt att förstå att han nu kan få både och:

Han hade fruktat för ångesten, men nu var den redan där. Och den var värre än någon ångest han förut känt, ty nu hade han ju allt vad hans själ hade längtat efter: en varelse som fullt förstod 
honom, och det hjälpte icke. Han levde i den innerligaste kärlek, men den kunde inte ge någon hel lycka. Självrannsakandet hade nu en gång fått makt med honom sedan så lång tid tillbaka, och det nådde honom, även när han låg i sin älskades famn. Hon var det härligaste, det ljuvaste, hon var fylld av Guds närhet, och det hjälpte honom ändå icke. (266)

Men hon lär sig förstå hans "personlighetsklyvning" och låter honom vara för sig själv när han behöver det så att de sedan ska kunna glädjas desto mera när de möts igen. De blir ett perfekt par.

Så långt romanen. Man kan undra hur i all sin dar Wahlström tänkte när hon i memoarerna pekade ut Daniel som sig själv och Carry som Anita? Läser man romanen i ljuset av "Personliga erfarenheter av psykoanalys" och memoarerna framstår den som häpnadsväckande utlämnande. Var hon bara obetänksam? Kanske tänkte hon att ingen längre skulle minnas romanerna? Eller var det så att hon ville ge sina läsare pusselbitar som kunde läggas ihop till en bild av henne själv som en lesbisk Don Juan? Som den historiker hon var kanske hon lade ut ledtrådar för den som ville läsa en öppnare berättelse än den hon kunde tillåta sig att publicera. ${ }^{34}$

Den paragraf som så länge hade kriminaliserat homosexualitet var avskaffad när Wahlström berättade om sin analys, "inte en dag för tidigt", tyckte Wahlström. Anita var död sedan åtta år och under hennes sista sjukdom var det inte Lydia som hade varit hos henne i Alingsås utan Karin Boye, som nu också var död. Kanske kände Wahlström sig därför fri att göra som hon ville med sitt material. I självbiografin berättar hon:

under nästan hela perioden 1920-1934 var jag starkt engagerad av mitt förhållande till en $\mathrm{f}$. $\mathrm{d}$. elev, som jag betraktade som min fosterdotter. Egentligen var det ju naturligt, om mina modersinstinkter fick impulser från min pedagogiska verksamhet, där jag uteslutande haft med flickor i övergångsåldern att göra. Endast en gång förut, omkring 1913-17 hade jag mer eller mindre allvarligt lekt med drömmen om vad jag kallade "storfursten-tronföljaren", men 1920, då jag under en cykeltur i södra Sverige närmare lärt 
känna Anita Nathorst, försökte jag på allvar realisera tanken om en lärjunge, som skulle bli arvtagare till min verksamhet både i historia, teologi och kvinnosak. (272)

Anita hade en gång varit Lydias elev, precis som romanens Carry har varit Daniels läsbarn. På en cykeltur några år efter skoltiden återknöt Anita och Lydia sin bekantskap precis som Carry och Daniel gör i romanen och de båda paren har dessutom det gemensamt att de åker till Italien. Men Biskopen är en kärleksroman som slutar lyckligt och det gjorde inte Lydias och Anitas relation. Efter några år blev det slitningar mellan dem, och en kamrat

sade mig, att [Anita] höll på att dra sig undan mitt inflytande. Hade jag genast accepterat detta, skulle jag ha besparat mig många svårigheter. Nu blev de följande åren ganska trassliga, desto mera som jag äntligen - just lagom innan jag skulle fylla sexti - hade börjat komma underfund med att också jag en gång skulle falla för åldersstrecket. (280)

\section{Sin fars dotter}

Emellan de båda romanerna om Daniel Malmbrink, där det förbjudna maskeras till heterosexualitet, kom Sin fars dotter, en berättelse där den samkönade kärleken i stället framställs som en fas i utvecklingen, något som går över om kvinnan bara träffar rätt man i rättan tid. ${ }^{35}$ Det hela läggs alltså fram ungefär så som den psykologiska litteraturen vid den här tiden så gärna ville framställa saken och kanske också så som Wahlström själv - halvhjärtat - försökte beskriva sin egen utveckling. Men också i denna roman sipprar det fram meningsmöjligheter som inte ryms i den heteronormativa ordningen.

Märta är den enda dottern i en stor syskonskara och får tidigt lära sig vad det innebär att tillhöra det andra könet. Hon får hjälpa till i hushållet, bistå bröderna med än det ena än det andra, och det är deras studier som uppmärksammas trots att det är Märta som är begåvningen i familjen. Men under berättelsens gång lyckas Märta 
med konststycket att både göra akademisk karriär och vinna faderns erkännande - och dessutom finna den rätte. Däremellan hinner hon med ett vänskapssvärmeri som skakar om henne.

Märta längtar efter kärlek och gemenskap men har inget självförtroende på (hetero)kärlekens område. Hon blir generad i umgänget med män och tycker sig sakna charm tillsammans med dem. Efter att ha funderat över vad det är som drar män och kvinnor till varandra kommer hon in på vad attraktionen mellan kvinnor kan tänkas bestå i:

Men var det inte precis på samma sätt i fråga om flickor? Ligger inte även den hemligheten djupare inne, i själva naturgrunden? Det var musiken och inget annat, som fört ihop Greta och Sonja, men musiken, det var ju det innersta i det innersta, den låg på gränsen mellan kropp och själ, brukade Sonja säga. Och Märtas egen antipati mot Astrid Cornér, den var så starkt blandad med dragningskraft, precis som romanerna påstod, att kärleken ibland kunde vara. Inte resonerade man sig till att älska någon varken $\mathrm{i}$ vänskap eller kärlek, och mellan dessa båda var det nog inte så stor skillnad, som folk försökte inbilla varandra i denna värld av brackor. ${ }^{36}$

Man kan se detta som en kritik mot en vanligt förekommande tankekliché att (hetero)kärlek handlar om hetta och passion medan den samkönade vänskapen, ja till och med kärleken, är lugn och förnuftsstyrd. För Märta är det inte så. De känslor hon har för Astrid Cornér är av en otyglad och brinnande sort. Samma sak med Greta och Sonja, som hittat varandra genom musiken, denna den mest sinnliga av konstformer.

Men var fanns all ömheten, godheten, barmhärtigheten helt enkelt i alla dessa förhållanden av temperament och naturgrund och charm? Var fanns det, som Märta längtade efter mer än efter något annat i världen - en människa, sak samma om kvinna eller man, som bara höll av henne och ville göra det ljust för hennes bråkiga, ärelystna, ständigt hungriga själ, utan att ens fråga efter genkärlek? 
Och hon grät sig till sömns vid tanken på den, som aldrig skulle komma. (65)

Hennes funderingar över vänskapens och kärlekens väsen mynnar ut $\mathrm{i}$ en längtan efter en människa, inte efter en man eller en kvinna.

Märtas känslor för Astrid Cornér har sinnliga inslag. När hon sover över hos Astrid känner hon "en vansinnig längtan att slå armarna tätt omkring henne och borra huvudet intill hennes bröst". (83) När Märta ser den andra kvinnan på en fest är det attraktion hon känner, "hon älskade till och med hennes lite osymmetriska, stötiga gång och den där mörkbruna crêpe-de chineklänningen med snörmakeri i gult silke, som passade så bra till hennes hår”. (101) Men Astrid tycker att Märta är alldeles för intensiv, för het i sina känslor och säger:

- Ser du, din vänskap för mig är av ett annat slag än min till dig. All den kärlek du gömt ihop, som du inte kunnat ödsla på föräldrar och en stor syskonkrets som jag eller få utlopp för i ungdomssvärmerier och sånt där skoj, det ger du åt mig. Och nog ger jag dig min vänskap, som jag hoppas för beständigt, men du vet, att jag är svalare än du, och din tillgivenhet bränner mig. (98)

Här blir det tydligt att det inte är någon lagom tempererad vänskap som Märta hyser utan något annat och mer. Uppgörelsen mellan de båda kvinnorna leder till kärlekssorg för Märta, för något annat kan det inte kallas. Men sorgen lättar så småningom: "Å, hon hade inte tänkt på Astrid på hela dagen! Tänk om den hopplösa kärleken till henne en gång skulle kunna vika för en annan kärlek." (129; min kurs.) Här betecknas de känslor hon tidigare kallade "vänskap" alltså som "kärlek".

Märta har också en annan kvinnlig kamrat, Elsa, Greven kallad, som hon sportar och har det trevligt med. Greven är glad och sällskaplig, men hon tycks inte vara Märtas typ som kärlekspartner betraktad. Nu är det Greven som är den passionerade, medan Märta är svalare. 
Greven tyckte hon såg ståtlig ut, där hon stod vid bordet med blicken på faderns porträtt. Elsas runda pojkansikte fick plötsligt ett uttryck av ömhet:

- Jag vill ha dig, kung Märta, sade hon skrattande, så att trubbnosen fick några lustiga rynkor, och lutade sig i detsamma fram och kysste henne på kinden. Men så blev hon generad för vad hon gjort - kamrater emellan brukades ju inte sådant där. (43)

"Jag vill ha dig" är ord som annars brukar reserveras för den erotiska (hetero)kärleken. Här utsägs de av en pojkaktig ung kvinna till en annan. Märta tänker när den andra har lämnat rummet att "den sorten var väldigt sympatisk". De blir varandras goda kamrater, men mer än så tycks Märta inte känna för henne - hon tycker att Greven är alldeles för pojkaktig.

Greven var nästan för enkel för hennes smak - pojke kunde ju Märta vara själv, om det anbelangade. Det var inte konstigare än att hålla händerna i kjolfickorna och sitta med foten lagd över knäet och blåsa ut cigarettröken genom näsan, men nog var det underligt att Greven aldrig tröttnade på de barnsligheterna. För Märta var sådant bara utanpåklistrat - och för resten tyckte ju pappa inte om det, han som envisades med att hon skulle vara flicka. På det hela taget längtade hon också ibland efter att känna sig vara helt det hon ändå inte kunde komma ifrån att vara. (59)

Greven spelar ut sin manlighet och även Märta känner sig i början av berättelsen stå närmare den "manliga" polen än den "kvinnliga". Tillsammans bildar de två ett slags pojkgemenskap, som för Märtas del inte har några erotiska övertoner, men som för Greven nog har det. Känslomässigt dras Märta till mer "kvinnliga" kvinnor, samtidigt som hon föraktar det traditionellt "kvinnliga", en motsägelsefull hållning hon som bekant delar med många män. Inte heller Märta trivs i den könsroll hon har blivit tilldelad, inte förrän hon vinner såväl faderns som sin blivande makes kärlek och respekt och kan förverkliga en ny form av kvinnlighet.

Precis som när det gäller de andra romanerna presenterar Wahl- 
ström i sin självbiografi en bakgrund hämtad från sitt eget liv till karaktärerna i Sin fars dotter. Astrid Cornérs motsvarighet i verkligheten sägs till exempel ha varit Polly Eidem. När Wahlström berättar om henne använder hon ordet "attraktion". ${ }^{37}$ Märtas blixtrande intelligente far sägs vara inspirerad av professorn Harald Hjärne, medan den unge man som så småningom blir hennes trolovade har lånat den blivande ärkebiskopen Nathan Söderbloms drag. ${ }^{38}$

I självbiografin skriver Wahlström att någon av dessa män skulle ha passat henne som make. Intelligens, förklarar hon, var avgörande för om hon skulle finna någon attraktiv eller inte och denna egenskap besatt både Söderblom och Hjärne. Problemet var bara att den ene var förlovad och den andre gift. "Jag hade ju alltid katekes eller kokbok för mitt uppförande, och där stod det bland annat, att en normal kvinna inte blev kär i andras äkta män, och då kunde jag naturligtvis inte bli det." ${ }^{39}$ Heterosexualiteten var därmed ett avslutat kapitel för hennes del. Eller rättare, ett oskrivet kapitel. Hon berättar:

Att jag sommaren 94, alltså vid 25 år, stod vid ett vägskäl, borde ha varit mig klart. I alla händelser hade det varit lyckligt om "den rätte" vid denna tid hade infunnit sig, så att mitt emotionella liv hade kunnat få erfara det livskamratskap och den samhällsplikt som ensamt skulle kunnat göra mig lugn och stadgad. Men vid denna tid var sambandet mellan kropp och själ ännu en terra incognita för även den bildade ungdomen, och konvenansen tillät inte några upptäckter där, annat än på smygvägar..$^{40}$

Om man läser romanen med självbiografin som intertext, framstår Sin fars dotter som en fantasi om hur Lydia hade kunnat utvecklas om hon hade fått någon av de män hon beundrade, om hur hon då hade kunnat leva upp till de psykologiska "kokböckernas" recept på hur en "kvinna" ska lagas till. Särskilt entusiastisk tycks Wahlström dock inte ha varit inför denna tanke - vid sidan av ordet "kamratskap" är det ju ordet "plikt" hon använder.

Föga förvånande blev det ingen erotisk helomvändning i Lydias liv. Hon drev allt djupare in i vänskapssvärmeriernas förtrollade värld, tills en dag Klara Johanson dök upp på scenen. I Sin fars dotter 
har hon tilldelats Grevens lite otacksamma roll och blir hållen på armlängds avstånd av Märta. I verkligheten klarade sig K. J. betydligt bättre. Efter en kort tids bekantskap hade hon flyttat in i Lydias hjärta och liv. Där tycks det inte ha funnits några betänkligheter på grund av hennes pojkaktighet. ${ }^{41}$

I stället kom just då en kvinnlig student, som inte begärde bättre än att få lägga beslag på mig. Och att hon, trots att hon var fem år yngre än jag, fick sin vilja fram efter ganska kort tid, berodde nog på att hon hade båda de egenskaper, som passade för mitt eget på samma gång förståndsmässiga och sentimentala kynne. "K.J” var både intellektuell och emotionell i hög grad, men därtill något av ett geni. ${ }^{42}$

\section{Personliga erfarenheter av psykoanalys}

Vid 65 års ålder började Wahlström i psykoanalys, vilket hon elva år senare öppenhjärtigt berättade om. "Har jag varit över hövan exhibitionistisk, så betalar jag kanske för andras bristande ärlighet", skriver hon, väl medveten om det kontroversiella i det hon hade att säga. ${ }^{43}$ "Personliga erfarenheter av psykoanalys" var en radikal text för sin tid och för den generation hon själv representerade. Det finns passager som pekar fram mot den homosexuella frigörelsekamp som skulle komma först flera decennier senare. ${ }^{44}$

Wahlström uppger att hon underkastade sig analysen av pedagogiskt intresse och för att kunna hjälpa en vän (nämligen Anita). Längre fram i texten berättar hon om erotiskt färgade svärmerier mellan äldre och yngre kvinnor, där parterna ikläder sig roller som mor och barn eller mästare och lärjunge. (Hon hade läst sin Platon.) Det är den äldres plikt att se till att "den farliga gränsen" aldrig överskrids, men om den gör det är det för att "den yngre under sin barndom blivit nervöst belastad och då gäller det för den äldre att föra henne till självkännedom, vilket ofta inte lyckas annat än genom analys". (48-49) Analysen framställs här alltså som en heterosexualiseringsprocess.

Under analysen hade Lydia "tydligt symboliska drömmar om 
snedvridenhet, såsom att en binnikemask kröp in i mitt hjärta 'från orätt sida' eller att visarna på mitt ur 'hängde snett', som det hette i drömmens språk”. (54-55) Symbolspråket är konstruerat kring tidens vanligaste ord för någon som älskar någon av samma kön - "sned", "vriden", "inverterad", "skev", "abnorm", "onormal" och så vidare. Hon berättar också om drömmar om ett orent djur som försöker lägga sig i hennes säng och om män hon en gång har känt. Efter att ha drömt om männen känner hon sig inte neurotisk på flera dagar. Lydia har gjort sin läxa.

Texten är skriven med den distanserade, förment vetenskapliga stil som var det gängse idiomet i dessa sammanhang, och de vanligaste teorierna om varför kvinnor älskar kvinnor dyker upp: i-bristpå-bättre, för-hämmad-med-män, nervös belastning, okunnighet samt ren tillfällighet. Men detta är bara den ena sidan av myntet, för texten innehåller samtidigt ett kraftfullt försvar för den samkönade kärleken.

Wahlström söker klarhet över sin egen sexualitet. "Kunde jag verkligen under ett långt liv av intellektuella sysselsättningar ha känt mig fullt tillfredsställd utan att efter 25-årsåldern ha haft någon närmare förbindelse, vare sig vänskaplig eller erotisk, med någon man?" (42) Tydligen tog hon teorin om heterosexualitetens hälsobringande effekter på allvar, för hon talade med folk om saken. Brita Mannerheim, dotter till Anna och Gideon Danell, berättar:

Det gick grums i vår julidyll när Lydia hade börjat gå i analys. Redan under julmiddagen tog hon upp olika sexualproblem, som var besvärande särskilt för Gideon. Och på en julbjudning hemma gick Lydia fram till min biologilärarinna, som var ogift, och frågade henne hur hon kunde vara "så normal", när hon inte haft någon man. Och värre var att Lydia frågade hennes skygga gifta syster om Lydia inte kunde få låna hennes man! Lydia var under sin analystid ofta helt avståndslös. [...] Senare återgick Lydia till sitt gamla självironiska och generösa sätt att vara. ${ }^{45}$

Wahlström genomgick sin analys i mitten av 1930-talet, en tid hon beskriver som monomant upptagen av driftslivet. Man läste Sexuell 
tidskrift, psykoanalytisk litteratur och D. H. Lawrences romaner och pratade om att "skaffa sig ett sexualobjekt". Får man tro Brita Mannerheim delade Lydia tidens fokus på det erotiska. Erik Hjalmar Linder vittnar om samma sak: "Sentimentalitet visste hon inte vad det var, och knappast blyghet heller, men prydhet allra minst." ${ }^{46}$

Själv tror jag att detta bara är halva sanningen. Vi minns det där om "vänskapserotik, som kunde börja i anden och lykta i köttet, men som i så fall alltid slutade med vämjelse och brytning och nytt letande efter idealet". (47) Den kluvenhet biskop Malmbrink led av tycks även ha plågat Lydia.

Sexuell orientering stod på dagordningen för samtalen med analytikern. "Ganska snart avkunnade han också min dom: Jag hade aldrig varit homosexuellt lagd men väl bisexuellt, vilket han ansåg vara den så gott som allmänna läggningen hos kvinnor." (56) Hon är uppenbart nöjd med sin diagnos, så nöjd att hon berättade om den för människor till och med utanför sin närmaste krets. ${ }^{47}$ Hon var känslomässigt beskaffad ungefär som alla andra kvinnor! Ska man tro på det? I så fall måste den heterosexuella polen ha varit liten och pliktbetonad och den homosexuella desto större och obändigare. Kanske kan man förklara saken med att "bisexuell" helt enkelt var så långt det var möjligt att gå vid denna tid om man ville bli uppfattad som en fullvärdig människa. "Homosexuell" var en kategori som bara förekom i sensationspressen eller i medicinska och psykologiska sammanhang. Ingen som kunde undvika det tog på sig den rollen i offentligheten.

När Wahlström i slutet av artikeln presenterar sin syn på hur såväl den världsliga som den kyrkliga själavården kan förbättras, går hon rakt på sak. Det behövs fler kvinnliga analytiker och samma sak gäller prästyrket. Såväl psykologin som teologin präglas av att de är skapade av och för (heterosexuella) män. ${ }^{48}$ Wahlström efterlyser ett omfattande reformarbete, inte minst inom kyrkan, och här var hon längre före sin tid än kanske i någon annan fråga. Varken kyrkan eller psykologin har ju gjort upp med sitt homofoba förflutna.

Vidare måste både homosexualitet och bisexualitet inom själavården få den uppmärksamhet som kvinnornas genom kriget oer- 
hört ökade övertalighet kräver. Det är möjligt att man i Tyskland kommer att söka bota detta genom att legalisera månggiftet. Här behöves för övrigt även den offentliga upplysning, som man hittills aldrig kunnat få, därför att dessa företeelser på grund av deras kriminalisering i den allmänna meningen blivit ett slags mysterium tremendum, som man inte kan tala om annat än viskande. Strafflagen har visserligen i detta avseende - inte en dag för tidigt - blivit uppmjukad, men det dröjer nog länge, innan det verkligen gått upp för allmänheten att också normala sexualförhållanden kunna vara fulla med "de dödas ben och all orenlighet", medan ett "onormalt", så att säga inför Gud, kan ha något av den verkliga kärlekens höghet över sig. (58)

Passagen börjar med att nämna "kvinnoöverskott", något som ofta dök upp när frågan om varför kvinnor valde att leva tillsammans kom på tal. Den tyska journalisten Anna Rüling hade påpassligt använt det i ett uppmärksammat tal 1904, ett tal som brukar räknas som ett av de första offentliga försvaren för kärleksrelationer mellan kvinnor. På så sätt framstod valet förstås som mindre kontroversiellt, men det faktum att Wahlströms text är skriven vid andra världskrigets slut, när miljoner och åter miljoner soldater hade stupat, gör att tankegången nog uppfattades som näraliggande. ${ }^{49}$

Artikeln publicerades ett år efter homosexualitetens avkriminalisering. Ett enda år - och Wahlström kom redan med förslag på hur positionerna skulle kunna flyttas fram en bra bit till! Det är först nu som det går att tala öppet om dessa frågor, menar hon, och det är precis det hon tycker att man ska göra. Hon kallar den samkönade kärleken för kulturens "mysterium tremendum", ett begrepp hon hade hämtad från Rudolf Ottos Das Heilige (1917). Enligt Otto har det heliga två motsatta uppenbarelseformer, den ena är "mysterium fascinans", som handlar om vördnad, fascination och attraktion, och den andra är "mysterium tremendum", som handlar om fruktan, ångest och bortstötande..$^{50}$ Att Wahlström lånar ett begrepp från teologin för att beskriva sexualiteten säger en hel del både om tiden och henne själv. Hon hade genomlevt decennier av stigande intresse för driftslivet, där heterosexualiteten var kulturens "mysterium fasci- 
nans" medan homosexualiteten var dess "mysterium tremendum". Det vittnar också om den underfundiga humor som ofta utmärker Wahlströms skrivsätt. Hon var fostrad i en viktoriansk förbudsmoral, men under sitt långa liv hann hon också med att uppleva en heterosexistisk påbudsmoral först i Ellen Keys tappning och sedan i Sigmund Freuds. "Huvudsaken var, att den s.k. kärleksförbindelsen skulle gälla en man", kommenterar hon syrligt. (51)

Orden om "de dödas ben" syftar på Matteusevangeliet 23:27 som lyder: "Ve eder, I skriftlärde och fariséer, I skrymtare, som ären lika vitmenade gravar, vilka väl utanpå synas prydliga, men inuti äro fulla av de dödas ben och all slags orenlighet!" Orden kan nog gälla såväl vetenskapens som religionens makthavare. Lydia Wahlströms eget credo är att det är kärleken och bara kärleken som helgar sexualiteten. 